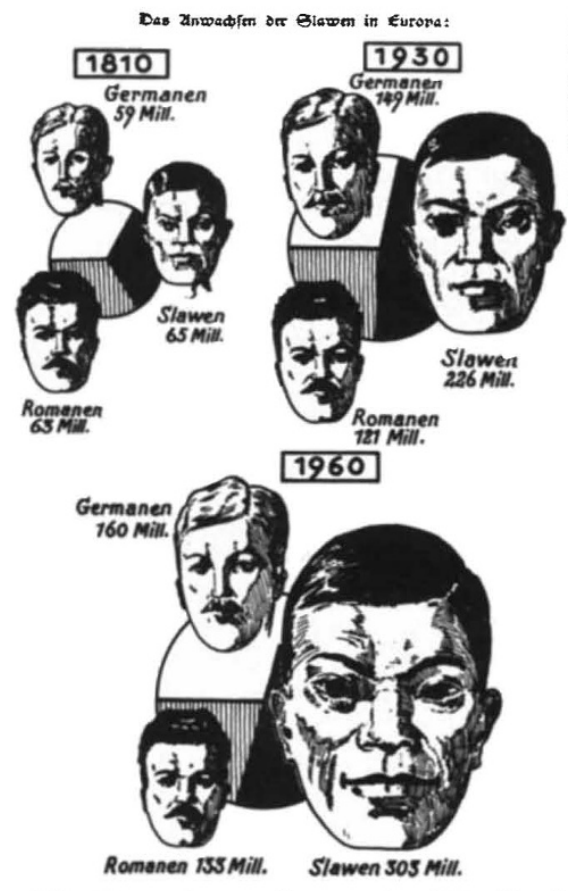

"Fertility and race, the growth of the Slav in Europe", from O. Helmut's Volk in Gefahr, 1934.

Weiss demonstrates convincingly that Wilhelm Schallmayer was opposed to the ideas of nordic supremacy and antisemitism. She calls Schallmayer's position "nonracist" but points out that as far as blacks were concerned Schallmayer was, like almost everybody else in the field, an outright racist. She recounts the story, often told in German publications, of how he won the competition set up in 1900 by Krupp - "What can we learn from the theory of evolution about internal political development and state legislation?"and outlines the goal of the competition. Its object was to wrest darwinism out of the hands of the labour movement and use it for eugenic legislation to increase the efficiency of the German capitalist state, just as the Krupps had made their steel mills more efficient. Weiss shows that, internationally, the aim of all the various brands of eugenics was to increase the efficiency of the state. But the later fatal development which, through the efforts of Baur, Fischer, Lenz and Rüdin, occurred in Germany in the 1920 s, has no place in her story because Schallmayer, her hero, died in 1919. I note a curious omission from this book: Nietzsche, who probably had a fundamental influence on Schallmayer's thinking, is not even mentioned.

Up to a point, these two volumes complement each other. But the book which describes the history of human genetics and its international darwinistic implications has yet to be written.

Benno Müller-Hill is a Professor in the Department of Genetics, University of Cologne, D $5000 \mathrm{Köln} \mathrm{41,} \mathrm{FRG.} \mathrm{An} \mathrm{English} \mathrm{translation}$ of his own book, Murderous Science: Elimination by Scientific Selection of Jews, Gypsies and Others, Germany 1933-1945, has just been published by Oxford University Press.

\section{Information on propagation}

Barry J. Everitt and Martin H. Johnson

The Physiology of Reproduction, Vols 1 \& 2. Editors-in-chief Ernst Knobil and Jimmy D. Neill. Raven:1988. Vol. 1 pp.1,390; Vol. 2 pp.1,021. \$362.50, £214.50

Wrry these two volumes, Knobil and Neill hope to "fill a need for a comprehensive, scholarly treatise on the physiology of mammalian reproduction". The scope of the work is as broad as would be expected from the title. Volume 1 is divided into three sections ("The Gametes, Fertilization and Early Embryogenesis"; "The Reproductive Systems", itself split into subsections devoted to the female and the male; and "The Pituitary and Hypothalamus"), Vol. 2 into two ("Reproductive Behavior and its Control"; and "Reproductive Processes and Their Control", the latter addressing topics such as puberty, cyclicity, pregnancy and reproductive senescence). The books are not profusely illustrated; of the illustrations that are included, many of the photographs are poor and the line illustrations rather thick textured.

The volumes are certainly scholarly. Most of the authors are established researchers who have made original contributions to the areas they review. Glancing at the table of contents gives the impression that the work is also comprehensive; the chapter titles bear little evidence of obvious omissions - although fetal physiology is perhaps one.

On reading further, some shortcomings become apparent. Although the editors assert that "it has been left to the reader to ascertain the similarities and differences" in reproductive processes among mammalian species, they have not always taken the trouble to ensure that the necessary, comparative information has been included. This is especially the case so far as human reproduction is concerned. Where a chapter covers the range of species, the human male or female are often mentioned only in passing or not at all. Where a group of chapters covers a single topic from a species perspective, for example "Puberty", there are discussions of the rat, the sheep, primates - but not the human being, despite the existence of a considerable clinical experimental literature on the subject.

The problem can be illustrated by reference to one contribution in particular, that by Pfaff on female reproductive behaviour. It is excellently written and reviews the author's own work on defining the neuroendocrine mechanisms which underlie the lordosis reflex in female rats. This important research, conducted by
Pfaff over many years, has enabled the dissection, with great precision, of the somatosensory pathways involved in the reflex, the ways in which ovarian hormones facilitate it, the neurochemical mechanisms involved and even the intracellular, molecular events set in train by oestrogen's action on nerve cells. But readers turning to this chapter to find out about the neuroendocrine control of sexual behaviour will be disappointed indeed, unless they are especially interested in the section on cellular principles. The hormonal basis of sexual behaviour in female primates, including women, is very different to that in the rat, and lordosis is a sexual reflex not even encountered in these species. This sort of failing is particularly irritating given the unnecessary duplication of material elsewhere. For example, the oviduct and its functions are covered in two or three places, as is epididymidal physiology.

However, many of the contributions are superb. In addition to that by Pfaff, those by Sachs, Numan, Plant, Turek, Challis, Pedersen and Setchell, among others, are informative, contemporary accounts of important topics. So although this is not a comprehensive textbook of reproductive physiology, it is an excellent collection of reviews which covers, albeit in a variable and idiosyncratic way, a wide range of areas of this broad field of research. True, many chapters are pitched at a high level, and to appreciate much of the information in the books it is necessary to have a considerable background knowledge not just of the subject as a whole, but of the specific topic of each chapter. For example, the plunge into the complexities of sex determination on the first page of Chapter 1 with a passing, unexplained reference to "Xsr" is going to lose many inexperienced readers rapidly.

Postgraduate students will find these volumes demanding. Experienced, postdoctoral researchers will find them, as we did, extremely valuable and informative. This work will be essential for every laboratory engaged in reproduction research and every library in scientific and medical environments where such research is being conducted. It is an impressive enterprise.

Barry J. Everitt and Martin H. Johnson are in the Department of Anatomy, University of Cambridge, Downing Street, Cambridge CB2 $3 D Y, U K$.

\section{New editions}

- Plant Molecular Biology, 2nd edn, by D. Grierson and S. N. Covey. Publisher is Blackie/ Chapman and Hall (New York), price is hbk $£ 27, \$ 45.75$; pbk £12.95, $\$ 21.95$. For review see Nature 314, 41 (1985)

- Microcomputers and Laboratory Instrumentation, 2nd edn, by D. J. Malcolme-Lawes. Publisher is Plenum, price is $£ 27.95, \$ 47.40$. For review see Nature 311, 313 (1984) 